\title{
Structure-guided design of antibacterials that allosterically inhibit DNA gyrase
}

\author{
Reema K. Thalji ${ }^{\mathrm{a}}$, Kaushik Raha ${ }^{\mathrm{a}}$, Daniele Andreotti ${ }^{\mathrm{b}}$, Anna Checchia ${ }^{\mathrm{b}}$, Haifeng Cui ${ }^{\mathrm{a}}$, Giovanni \\ Meneghelli $^{\mathrm{b}, \mathrm{c}}$, Roberto Profeta ${ }^{\mathrm{b}, \mathrm{c}}$, Federica Tonelli $^{\mathrm{b}}$, Simona Tommasi ${ }^{\mathrm{b}, \mathrm{c}}$, Tania Bakshi ${ }^{\mathrm{a}}$, Brian T. Donovan ${ }^{\mathrm{a}}$, \\ Alison Howells ${ }^{\mathrm{d}}$, Shruti Jain ${ }^{\mathrm{d}}$, Christopher Nixon ${ }^{\mathrm{a}}$, Geoffrey Quinque ${ }^{\mathrm{a}}$, Lynn McCloskey ${ }^{\mathrm{a}}$, Benjamin D. \\ Bax $^{\mathrm{e}, \mathrm{f}}$, Margarete Neu ${ }^{\mathrm{f}}$, Pan F. Chan ${ }^{\mathrm{a},}$ and Robert A. Stavenger ${ }^{\mathrm{a},{ }^{*}}$ \\ ${ }^{a}$ GlaxoSmithKline, Collegeville, PA 19426, USA, ${ }^{b}$ EVOTEC Center of Drug Discovery and Development, 37135, Verona, Italy, ${ }^{c}$ Current address: Fabbrica \\ Italiana Sintetici (FIS), 36075, Montecchio Maggiore, Vicenza, Italy, ${ }^{d}$ Inspiralis Ltd. Innovation Centre, Norwich, NR4 $7 G J$, UK, ${ }^{e}$ Current address: Medicines \\ Discovery Institute, Cardiff University, Main Building, Park Place, Cardiff CF10 3AT, UK, ${ }^{f}$ GlaxoSmithKline, Stevenage, Hertfordshire, SG1 2 NYH, UK.
}

\begin{abstract}
A series of DNA gyrase inhibitors were designed based on the X-ray structure of a parent thiophene scaffold with the objective to improve biochemical and whole-cell antibacterial activity, while reducing cardiac ion channel activity. The binding mode and overall design hypothesis of one series was confirmed with a co-crystal structure with DNA gyrase. Although some analogs retained both biochemical activity and whole-cell antibacterial activity, we were unable to significantly improve the activity of the series and analogs retained activity against the cardiac ion channels, therefore we stopped optimization efforts.
\end{abstract}

Multi-drug resistant (MDR) bacteria, especially MDR Gramnegative bacteria, are a rising public health threat. Without effective antibiotic therapy, many mainstays of modern medicine such as chemotherapy and major surgery would not be possible. ${ }^{1}$ This high unmet medical need has been noted by societies, ${ }^{2}$ governments, ${ }^{3}$ and even the United Nations. ${ }^{4}$ Due to this, the need to discover and develop novel treatments for resistant bacterial infections is higher than ever. To address this need, new ways of working are required. ${ }^{5}$ One example of this is the Innovative Medicines Initiative's ENABLE project, whose aim is to optimize hits and leads which target Gram-negative bacteria in semi-open innovation, consortium format. ${ }^{6}$ As part of the ENABLE project, we recently reported a series of thiophene-based antibacterials which target the bacterial topoisomerase DNA gyrase via binding to a previously unidentified allosteric site on the enzyme. ${ }^{7}$ The bacterial topoisomerases DNA gyrase and topoisomerase IV are essential enzymes which control DNA topology and are the targets of the clinically validated fluoroquinolone antibiotics, in addition to several other classes reported in the literature ${ }^{8}$ or in clinical development. ${ }^{9}$

The thiophene-based antibacterial 1 (Figure 1) is an inhibitor of bacterial DNA gyrase with modest antibacterial activity against a range of Gram-negative bacterial pathogens. ${ }^{7}$ Unlike most other inhibitors of bacterial topoisomerases, the lead compound $\mathbf{1}$ only showed significant activity against DNA gyrase with essentially no activity against the related enzyme topoisomerase IV ( $\mathrm{IC}_{50}$ $>500 \mu \mathrm{M}^{7}$ in a decatenation of kinetoplast DNA inhibition assay). As part of an overall medicinal chemistry program on this series, we sought to modify the core of these inhibitors. Examination of the binding mode of $\mathbf{1}$ to Staphylococcus aureus (S. aureus) DNA gyrase $^{7}$ (Figure 3A) suggested that two cyclization strategies to bicyclic templates could be tolerated (Figure 1). Ring closure route a retains the thiophene core and fuses a 6-ring heterocycle, while ring closure route $\mathbf{b}$ changes the thiophene to a 6 -membered benzo- or heterocycle and fuses a 5- or 6-membered heterocycle. We hypothesized that appropriately constraining the core ${ }^{10}$ might improve biochemical activity at DNA gyrase; here we report our results on the synthesis and evaluation of exemplars of both cyclization approaches (Figure 2).

The gyrase inhibitors $\mathbf{2}$ through 12 (Figure 2) were synthesized as described in Schemes 1-7. The synthesis of thieno[3,2d]pyrimidin-4 $(3 \mathrm{H})$-one core inhibitor 2 , derived from ring closure route a (Figure 1), started with commercially available thiophene 13 (Scheme 1). Installation of the 2-chlorophenyl group via Suzuki coupling followed by saponification provided the corresponding carboxylic acid. PyBOP-mediated coupling with the protected $(S)$-phenylethylenediamine provided 14. Heating in the presence of trimethoxymethane and acetic anhydride provided the cyclized product which was deprotected with trifluoracetic acid to give compound 2 . 


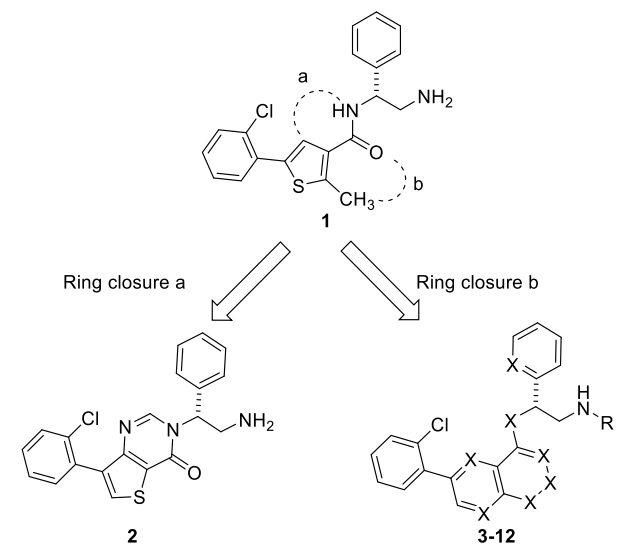

Figure 1. Gyrase inhibitor 1 and new bicyclic designs.

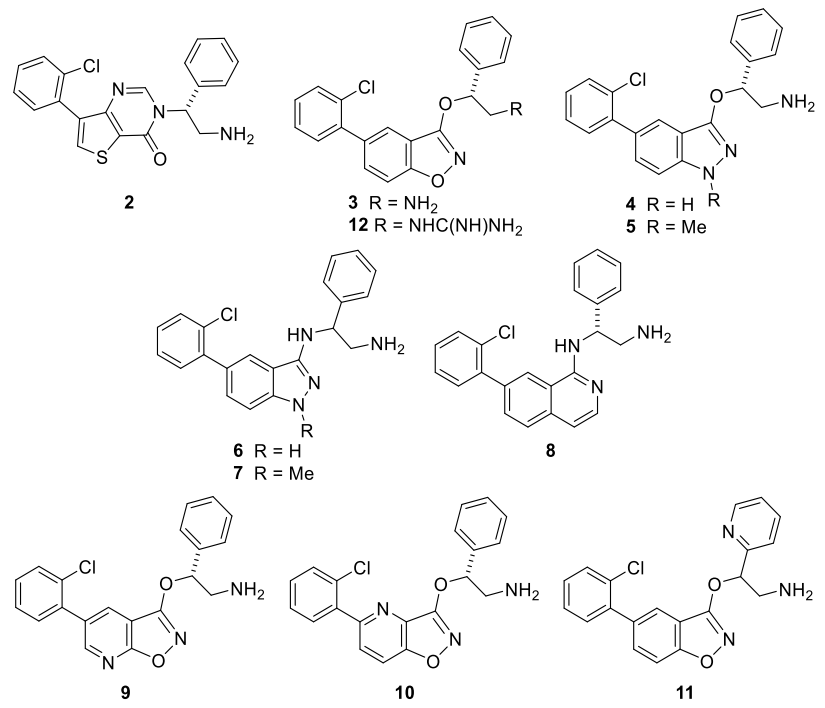

Figure 2. DNA gyrase inhibitors disclosed in this paper.

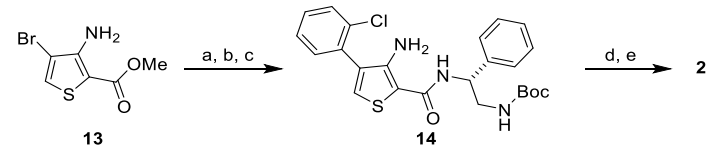

Scheme 1. Reagents and conditions: (a) 2-chlorobenzeneboronic acid, $\mathrm{K}_{2} \mathrm{CO}_{3}, \mathrm{Pd}\left(\mathrm{PPh}_{3}\right)_{4}$, dioxane, $\mathrm{H}_{2} \mathrm{O}, 100{ }^{\circ} \mathrm{C}, 98 \%$; (b) $\mathrm{LiOH}, \mathrm{MeOH}, \mathrm{H}_{2} \mathrm{O}, 86 \%$; (c) N-Boc- $(S)$-phenylethylenediamine, $i$ Pr $_{2} \mathrm{NEt}$, PyBOP, MeOH, 67\%; (d) trimethoxymethane, $\mathrm{Ac}_{2} \mathrm{O} 100{ }^{\circ} \mathrm{C}, 25 \%$; (e) TFA, $\mathrm{CH}_{2} \mathrm{Cl}_{2}, 61 \%$.

The synthesis of $\mathbf{3}$ and derivatives $\mathbf{1 1}$ and $\mathbf{1 2}$ is described in Scheme 2. Arylation of bromide $\mathbf{1 5}$ provided $\mathbf{1 6}$ followed by formation of the $N$-hydroxy amide under basic conditions followed by cyclization with carbonyldiimidazole provided the key benzisoxazolone intermediate $\mathbf{1 7}$. Treatment with alcohol $\mathbf{1 8}$ under Mitsunobu conditions afforded the desired $O$-alkylated product 21. Formation of the $\mathrm{HCl}$ salt afforded target compound $\mathbf{3}$. Alternatively, reaction of $\mathbf{2 1}$ with 1H-pyrazole-1carboximidamide followed by $\mathrm{HCl}$ salt formation provided the guanidine analog 12. In an analogous manner, intermediate 17 was coupled with Boc-protected 2-amino-1-(pyridin-2-yl)ethanol (19), followed by deprotection and salt formation to give target $\mathbf{1 1}$.

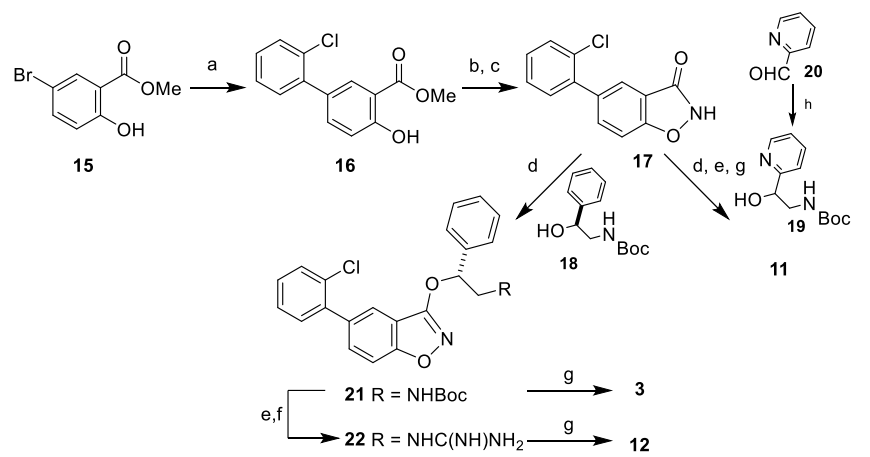

Scheme 2. Reagents and conditions: (a) 2-chlorobenzeneboronic acid, CsF, $\mathrm{Pd}\left(\mathrm{PPh}_{3}\right)_{4}$, DMF, $\mathrm{H}_{2} \mathrm{O}, 100{ }^{\circ} \mathrm{C}, 30 \%$; (b) $\mathrm{NH}_{2} \mathrm{OH}$, dioxane, aq. $\mathrm{NaOH}, 89 \%$.; (c) $\mathrm{CDI}, \mathrm{Et}_{3} \mathrm{~N}$, THF, $60{ }^{\circ} \mathrm{C}, 79 \%$; (d) alcohol, $\mathrm{PPh}_{3}$, DIAD, THF, rt; (e) TFA, $\mathrm{CH}_{2} \mathrm{Cl}_{2}$; (f) 1H-pyrazole-1-carboximidamide, $\mathrm{Pr}_{2} \mathrm{EtN}, \mathrm{CH}_{2} \mathrm{Cl}_{2}, 49 \%$ over 2 steps; (g) $\mathrm{HCl}, \mathrm{Et}_{2} \mathrm{O}$; (h) 1) $\mathrm{MeNO}_{2}$. Triton-B, $\mathrm{MeOH}, 0{ }^{\circ} \mathrm{C}$; 2) $\mathrm{LiAlH}_{4}, \mathrm{THF}$, $40{ }^{\circ} \mathrm{C}, \mathrm{Boc}_{2} \mathrm{O}, \mathrm{NaHCO}_{3}, \mathrm{THF} / \mathrm{H}_{2} \mathrm{O}$ (5\% over 3 steps).

The synthesis of $O$-alkylated indazoles $\mathbf{4}$ and $\mathbf{5}$ proceeded with a similar route and is shown in Scheme 3, starting with Suzuki coupling and methyl ester formation to give 24. Displacement of the aryl fluoride with hydrazine at $100{ }^{\circ} \mathrm{C}$, followed by protection/activation with Boc-anhydride and treatment with a strong base gave the indazolanone core 25. Mitsunobu reaction with alcohol 18 followed by removal of the Boc group with trifluoracetic acid and swapping to the $\mathrm{HCl}$ salt gave target compound $\mathbf{4}$. Selective protection of the primary amine of $\mathbf{4}$ with Boc-anhydride followed by methylation of the indazole nitrogen with iodomethane, deprotection, and salt switching gave compound $\mathbf{5}$.

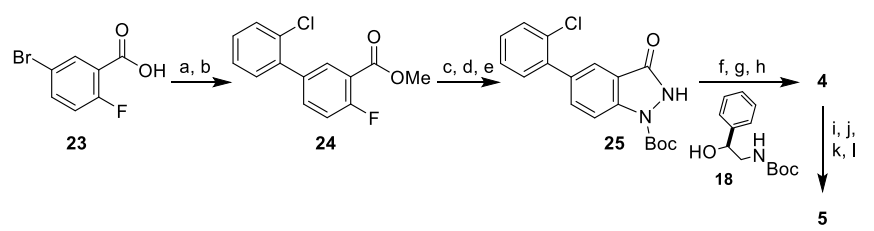

Scheme 3. Reagents and conditions: (a) 2-chlorobenzeneboronic acid, $\mathrm{Cs}_{2} \mathrm{CO}_{3}, \mathrm{Pd}\left(\mathrm{PPh}_{3}\right)_{4}$, dioxane, $\mathrm{H}_{2} \mathrm{O}, 100{ }^{\circ} \mathrm{C}, 91 \%$; (b) $\mathrm{SOCl}_{2}$, tol, $\mathrm{MeOH}, 92 \%$; (c) hydrazine, $\mathrm{MeOH}, 100{ }^{\circ} \mathrm{C}, 75 \%$; (d) $\mathrm{Boc}_{2} \mathrm{O}$, $\mathrm{Pr}_{2} \mathrm{NEt}$, DMAP, $\mathrm{CH}_{2} \mathrm{Cl}_{2}$; (e) aq. $\mathrm{NaOH}, 71 \%$ over 2 steps; (f) 19, $\mathrm{PPh}_{3}$, DIAD, THF, rt; 73\%; (g) TFA, $\mathrm{CH}_{2} \mathrm{Cl}_{2}$; (h) $\mathrm{HCl}, \mathrm{Et}_{2} \mathrm{O}, 67 \%$ over 2 steps; (i) $\mathrm{Boc}_{2} \mathrm{O}, \mathrm{NaHCO}_{3}$, THF, $0{ }^{\circ} \mathrm{C}$; (j) MeI, $\mathrm{K}_{2} \mathrm{CO}_{3}$, DMF; (k) TFA, $\mathrm{CH}_{2} \mathrm{Cl}_{2}$; (l) $\mathrm{HCl}, \mathrm{Et}_{2} \mathrm{O}, 33 \%$ over 4 steps from 5.

The synthesis of the $N$-alkylated indazoles 6 and 7 started with arylation of 5-bromo-indazole (26) followed by iodination in the presence of a strong base to give compound 27 (Scheme 4). Blocking the $\mathrm{N} 1-\mathrm{H}$ upon reaction with either Boc-anhydride or iodomethane provided compounds $\mathbf{2 8}$ and 29, respectively, which were each aminated using palladium catalysis and benzophenone imine followed by treatment with hydroxylamine to give the 3amino analogs 30 and 31, respectively. Heating with nitrostyrene provided the 1,4-addition products which were reduced with nickel boride in cold $\mathrm{THF} / \mathrm{methanol}$. Trifluoracetic acid deprotection of the $N$-Boc group of $\mathbf{3 0}$ and formation of the $\mathrm{HCl}$ salt provided target compound $\mathbf{6}$. Target 7 was made similarly from $\mathbf{3 1}$ by simple formation of the $\mathrm{HCl}$ salt following reduction of the nitrostyrene adduct. 


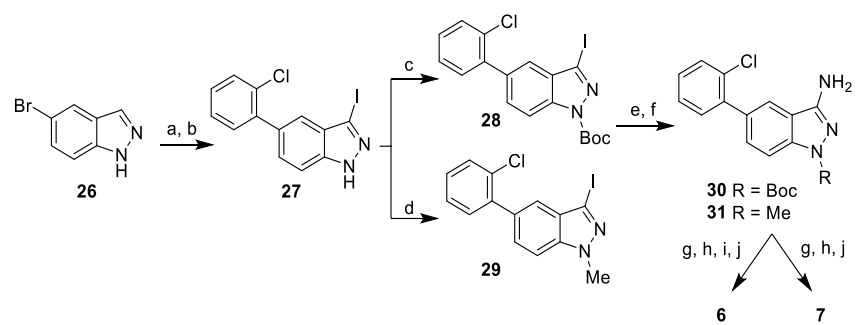

Scheme 4. Reagents and conditions: (a) 2-chlorobenzeneboronic acid, $\mathrm{Cs}_{2} \mathrm{CO}_{3}, \mathrm{Pd}\left(\mathrm{PPh}_{3}\right)_{4}$, dioxane, $\mathrm{H}_{2} \mathrm{O}, 160{ }^{\circ} \mathrm{C}, 70 \%$; (b) $\mathrm{I}_{2}, \mathrm{KOH}, \mathrm{DMF}$; (c) $\mathrm{Boc}_{2} \mathrm{O}$, $\mathrm{Et}_{3} \mathrm{~N}$, DMAP, $\mathrm{CH}_{3} \mathrm{CN}, 75 \%$ over 2 steps; (d) $\mathrm{MeI}, \mathrm{K}_{2} \mathrm{CO}_{3}, \mathrm{DMF}, 90 \%$; (e) benzophenone imine, $\mathrm{Pd}_{2}(\mathrm{dba})_{3}$, xantphos, $\mathrm{Cs}_{2} \mathrm{CO}_{3}$, dioxane, $100{ }^{\circ} \mathrm{C}$, (f) $\mathrm{NH}_{2} \mathrm{OH}, \mathrm{MeOH}, 45-47 \%$ over 2 steps; (g) nitrostyrene, $60{ }^{\circ} \mathrm{C}, 46-53 \%$; (h) $\mathrm{NiCl}_{2}, \mathrm{NaBH}_{4}, \mathrm{MeOH}$, THF, $-20^{\circ} \mathrm{C}$; (i) TFA, $\mathrm{CH}_{2} \mathrm{Cl}_{2}$; (j) $\mathrm{HCl}, \mathrm{Et}_{2} \mathrm{O}$.

The synthesis of isoquinoline 8 started with $\mathrm{S}_{\mathrm{N}} \mathrm{Ar}$ reaction of compound 32 with mono-protected diamine 33 (Scheme 5). Suzuki coupling with 2-chlorobenzeneboronic acid provided compound 34 followed by deprotection of the $N$-Boc group, and formation of the $\mathrm{HCl}$ salt gave target compound $\mathbf{8}$.

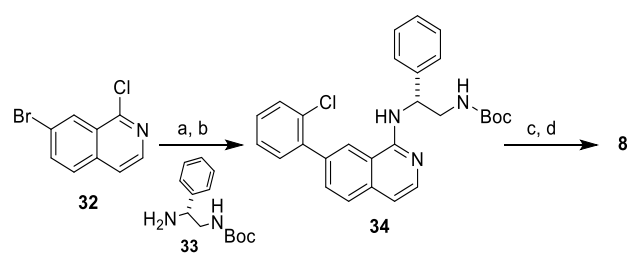

Scheme 5. Reagents and conditions: (a) 34, Pyridine, $145^{\circ} \mathrm{C}$ microwave; (b) 2-chlorobenzeneboronic acid, $\mathrm{Cs}_{2} \mathrm{CO}_{3}, \mathrm{Pd}\left(\mathrm{PPh}_{3}\right)_{4}$, dioxane, $\mathrm{H}_{2} \mathrm{O}, 130{ }^{\circ} \mathrm{C}$ microwave; (c) TFA, $\mathrm{CH}_{2} \mathrm{Cl}_{2}$; (d) $\mathrm{HCl}, \mathrm{Et}_{2} \mathrm{O}, 12 \%$ over 4 steps.

Synthesis of the pyridylisoxazole 9 is shown in Scheme 6. Treatment of 5-bromo-2-hydroxynicotinic acid (35) with thionyl chloride and methanol with a catalytic amount of DMF provided the corresponding methyl ester. Formation of the $N$-hydroxyamide followed by sodium hydroxide-promoted cyclization gave the fused isoxazolopyridinone 36. Successive Mitsunobu reaction with alcohol 18, Suzuki coupling, deprotection and $\mathrm{HCl}$ salt formation gave the target 9 .

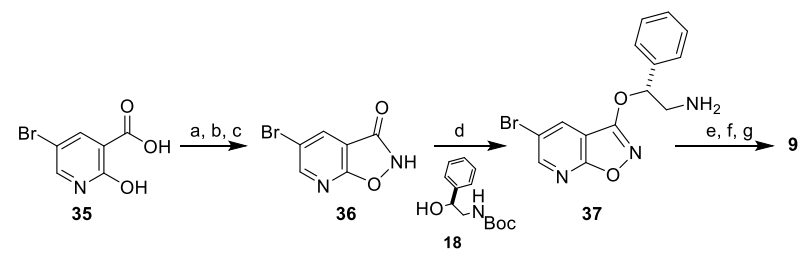

Scheme 6. Reagents and conditions: (a) $\mathrm{SOCl}_{2}$, DMF, $\mathrm{MeOH}, 65^{\circ} \mathrm{C}, 98 \%$; (b) $\mathrm{NH}_{2} \mathrm{OH}$, dioxane, aq. $\mathrm{NaOH}, 94 \%$; (c) $\mathrm{NaOH}, 70{ }^{\circ} \mathrm{C}, 59 \%$; (d) $\mathrm{PPh}_{3}, \mathrm{DIAD}$, THF, rt, 68\%; (e) 2-chlorobenzeneboronic acid, CsF, $\mathrm{Pd}\left(\mathrm{PPh}_{3}\right)_{4}, \mathrm{DMF}, \mathrm{H}_{2} \mathrm{O}$, $100{ }^{\circ} \mathrm{C}$, (f) TFA, $\mathrm{CH}_{2} \mathrm{Cl}_{2}$; (g) $\mathrm{HCl}, \mathrm{Et}_{2} \mathrm{O}, 18 \%$ over 3 steps.

Scheme 7 shows the synthesis of inhibitor 10. Conversion of 38 to the corresponding methyl ester followed by bromination gave compound 39. Suzuki coupling followed by treatment with hydroxylamine under basic conditions gave compound $\mathbf{4 0}$. Cyclization with carbonyldi-imidazole gave intermediate $\mathbf{4 1}$ which was treated with alcohol $\mathbf{1 8}$ under Mitsunobu conditions, followed by deprotection and formation of the $\mathrm{HCl}$ salt to give $\mathbf{1 0}$.

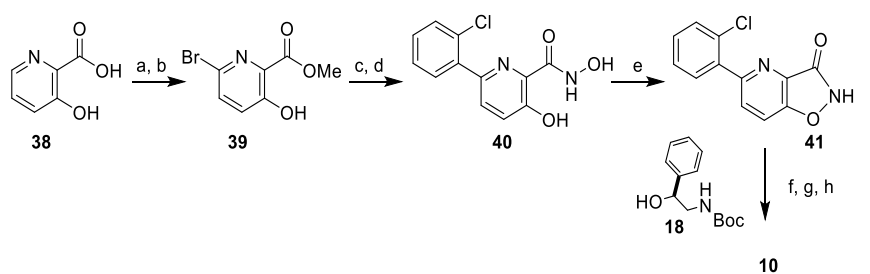

Scheme 7. Reagents and conditions: (a) $\mathrm{TMSCHN}_{2}, \mathrm{CH}_{2} \mathrm{Cl}_{2}, \mathrm{MeOH}$; (b) $\mathrm{Br}_{2}, \mathrm{H}_{2} \mathrm{O}, 42 \%$ over 2 steps; (c) 2-chlorobenzeneboronic acid, $\mathrm{CsF}, \mathrm{Pd}\left(\mathrm{PPh}_{3}\right)_{4}$, DMF, $100{ }^{\circ} \mathrm{C}, 16 \%$; (d) $\mathrm{NH}_{2} \mathrm{OH}$, dioxane, aq. $\mathrm{NaOH}$; (e) $\mathrm{CDI}, \mathrm{Et}_{3} \mathrm{~N}, \mathrm{CH}_{2} \mathrm{Cl}_{2}$, $23 \%$ over 2 steps; (f) 19, $\mathrm{PPh}_{3}$, DIAD, THF, rt; (g) TFA, $\mathrm{CH}_{2} \mathrm{Cl}_{2}$ (h) HCl, $\mathrm{Et}_{2} \mathrm{O}$, $29 \%$ over 3 steps.

The cyclized analogs of compound $\mathbf{1}$ were initially tested in a DNA gyrase biochemical assay ${ }^{11}$ and profiled against a panel of Gram-negative organisms, ${ }^{12}$ in addition to a mammalian cytotoxicity assay in mouse LY5178Y TK $+/$ - cells ${ }^{13}$ (Table 1). Inhibitor 2, representing ring closure strategy a (Figure 1), retained modest inhibition of DNA gyrase and demonstrated an improvement in cytotoxicity over the parent thiophene analog. Unfortunately, no whole cell antibacterial activity was observed across the range of wild-type (WT) Gram-negative pathogens tested (MICs $>128 \mu \mathrm{g} / \mathrm{mL}$ ). Activity could be detected when efflux was impaired by deletion of tolC in Escherichia coli (E. coli $\Delta$ tolC MIC $=2-4 \mu \mathrm{g} / \mathrm{mL}$ ) suggesting that efflux was a contributor to the lack of WT antibacterial activity. ${ }^{14}$ On-target activity at DNA gyrase was confirmed by an 8-fold shift in MIC against an E. coli $\Delta$ tolC GyrB E793K ${ }^{7}$ target mutant (a mode-of-action tool strain) relative to the isogenic parental strain. Due to the lack of activity against WT strains, additional analogs in this series were not pursued.

Initial investigation of the scope of ring closure strategy $\mathbf{b}$ (Figure 1) resulted in compounds 3-8, representing 3-O-alkyated benzoisoxazoles, 3-O- and 3-N-alkyated indazoles, and 1-Nalkylated isoquinolines. The benzoisoxazole $\mathbf{3}$ demonstrated promising DNA gyrase biochemical activity and modest (8-16 $\mu \mathrm{g} / \mathrm{mL}$ ) activity against WT E. coli and Acinetobacter baumannii (A. baumannii), with activity against Klebsiella pneumoniae (K. pneumoniae) and Pseudomonas aeruginosa (P. aeruginosa) being considerably weaker (MICs $\geq 128 \mu \mathrm{g} / \mathrm{mL}$, not shown). Very potent activity was observed in the efflux knock-out stains and the $\geq 16$ fold shift in MIC in the GyrB E793K mutant demonstrated ontarget activty (Table 1).

To confirm that the binding mode of compound $\mathbf{3}$, we initially solved a $2.7 \AA$ co-crystal structure with $S$. aureus DNA gyrase and 20-12p-8 double nicked DNA. ${ }^{15}$ This showed that compound 3 indeed bound as expected (Figure 3B) to the same allosteric site as compound $1 .^{7}$ The DNA used for this structure contained artificial nicks at each binding site, and the central four base-pairs of the DNA were not well defined in electron density maps. To try to obtain a clear view of a DNA-cleavage complex with compound 3 (see next paragraph), we repeated the structural studies using a purified DNA-cleavage complex with 20-447T DNA. ${ }^{15}$ We obtained a $3.4 \AA$ crystal structure of compound 3 co-crystallized with a purified DNA-cleavage complex of $S$. aureus gyrase. This $3.4 \AA$ structure showed compound 3 bound as seen in the $2.7 \AA$ structure, as expected (data not shown).

We have previously reported that compound 1 gave both singleand double-stranded DNA cleavage with E. coli DNA gyrase. ${ }^{7}$ Using a fusion truncate of DNA gyrase from K. pneumoniae, we showed that compound $\mathbf{3}$ also enhanced single-stranded and double-stranded DNA cleavage products (data not shown) indicating the mechanism of action of compound $\mathbf{3}$ is via stabilization of ternary cleaved complexes. In addition to 
inhibition of DNA gyrase ( $\mathrm{IC}_{50}=0.16 \mu \mathrm{M}$, Table 1$)$, compound 3 weakly inhibited $E$. coli TopoIV activity $\left(\mathrm{IC}_{50}\right.$ was $\sim 90 \mu \mathrm{M}$ in a decatenation of kinetoplast DNA inhibition assay $\left.{ }^{16}\right)$ and induced TopoIV-mediated DNA cleavage breaks (data not shown), and was also weakly active against the human enzyme $\left(\mathrm{IC}_{50}\right.$ was $\sim 210$ $\mu \mathrm{M}$ against human topoisomerase II $\alpha$ in a decatanation of $\mathrm{kDNA}$ inhibition assay $^{16}$ ).

Encouraged by the initial data of compound $\mathbf{3}$ and validation of the ring closure b hypothesis, several related 5,5 and 5,6 fused heterocycles were prepared (4-8). Relative to compound 3, these analogs had reduced DNA gyrase activity and weaker antimicrobial activity in WT and efflux knock-out strains of $E$. coli and WT $A$. baumannii (Table 1). Interestingly, slight improvements in activity against $K$. pneumoniae relative to compound $\mathbf{3}$ were observed for some analogs. Like compound $\mathbf{3}$, none of the newer analogs possessed activity against WT $P$. aeruginosa (MIC $>128 \mu \mathrm{g} / \mathrm{mL}$ ). Unfortunately, whole cell ontarget activity was not demonstrated for these analogs as no MIC shift was observed in the E. coli GyrB E793K mutant, perhaps suggesting that some of the activity observed is not solely due to inhibition of DNA gyrase.

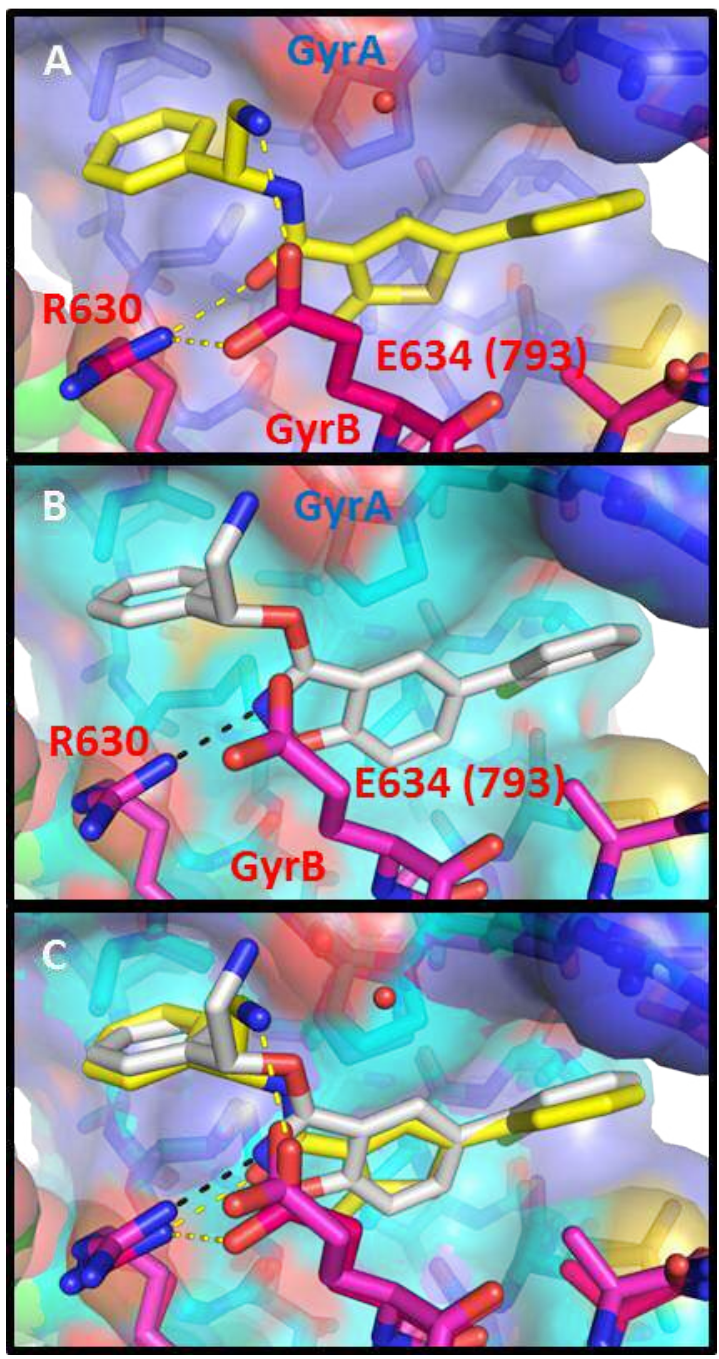

Figure 3. A) $2.22 \AA$ crystal structure (pdb code: $5 \mathrm{NPP}$ ) of $\mathbf{1}$ (yellow carbons) in complex with $S$. aureus DNA gyrase (GyrA blue carbons, GyrB magenta carbons) and DNA (green atom, lower left) ${ }^{7}$. Nitrogens blue, oxygens red, phosphorous orange chlorine green. Semi-transparent surface is shown on GyrA but not GyrB. Semi-transparent surface is shown on GyrA but not GyrB. Hydrogen bonds (dotted yellow lines) from E634 (=E793 in E.coli) go to 1 and R630. R630 also forms H-bonds to 1. B) $2.7 \AA$ crystal structure of 3 (white carbons) in complex with $S$. aureus DNA gyrase and DNA (pdb code: 6QX1). Hydrogen bond is shown as black dotted line. Note, the hydrogen bonds from
R630 to 3 is similar to that in panel A from R630 to 1; but no H-bonds are observed to E634 with 3 (maybe because of a small movement of the end of the side-chain of R630). C) Superposition of crystal structures in A and B. Figure drawn with pymol (The PyMOL Molecular Graphics System, Schrödinger, LLC).

As analogs 4-98 displayed disappointing antibacterial activities, we returned to the benzisoxazole scaffold of compound $\mathbf{3}$ and synthesized the three aza-analogs 9-11 and the guanidine $\mathbf{1 2}$. Although all analogs retained modest to good levels of activity against DNA gyrase, none showed an improvement in antibacterial activity in either WT or efflux strains of E. coli (12 gave a 2-fold improvement against $A$. baumannii, Table 2). No activity (MIC $>128 \mu \mathrm{g} / \mathrm{mL}$ ) was observed against $K$. pneumoniae and $P$. aeruginosa, except for compound $\mathbf{1 2}$ which gave an MIC of 16 $\mu \mathrm{g} / \mathrm{mL}$ against both $K$. pneumoniae and $P$. aeruginosa (data not shown). On-target activity was maintained for some (e.g. 9 and 11) but was less clear for analogs $\mathbf{1 0}$ and $\mathbf{1 2}$. Indeed, the broader spectrum activity of compound $\mathbf{1 2}$ could be due to an additional non-specific mechanism of action, potentially related to the guanidine substituent which is installed in an effort to alter the polarity of the series.

Despite the disappointing antibacterial activity, we tested several analogs against cardiac ion channels to determine if rigidifying the core would impact these activities (Table 2). Although 3 did have attenuated inhibition of both the hERG ${ }^{17}$ and $\mathrm{Na}_{\mathrm{V}} 1.5^{18}$ channels compared to compound 1 (Table 2), the effect was not dramatic. Compounds $\mathbf{9 , 1 0}$, and 12 also retained relatively potent inhibition against one or both of the cardiac ion channels tested, highlighting the difficulty in optimizing safety parameters in addition to activity in antibacterial research and development.

In summary, we have synthesized and tested several 5,6 and 6,6 fused core analogs of thiophene antibacterial 1 . Although both initial design hypotheses were successful in delivering analogs with in vitro activity against DNA gyrase, none of the analogs had improved whole cell antibacterial activity relative to the parent compound 1. Moreover, several liabilities of the series, specifically cytotoxicity and cardiac ion channel activity, were not mitigated with this ring-fusion strategy. As such, we stopped work on the present ring-fusion approach. A complete account of our efforts on monocyclic series, including liabilities and reasons for termination, ${ }^{7}$ will be reported separately. 
Table 1. Biochemical and bacterial susceptibility data for bicyclic gyrase inhibitors 1-8.

\begin{tabular}{|c|c|c|c|c|c|c|c|c|}
\hline Cmpd & $\begin{array}{c}\text { DNA } \\
\text { Gyrase } \\
\mathrm{IC}_{50}\end{array}$ & $\begin{array}{c}\text { E.coli } \\
\text { TOP10 } \\
\Delta t o l C\end{array}$ & $\begin{array}{c}\text { E.coli } \\
\text { TOP10 } \Delta t o l C \\
\text { GyrB E793K }\end{array}$ & $\begin{array}{c}\text { E.coli } \\
7623\end{array}$ & $\begin{array}{c}\text { E.coli } \\
7623 \\
\Delta t o l C\end{array}$ & $\begin{array}{c}\text { K. pneumoniae } \\
1161486\end{array}$ & $\begin{array}{l}\text { A. baumannii } \\
\text { BM4454 }\end{array}$ & $\begin{array}{c}\text { Cytotoxicity } \\
\mathrm{TC}_{50}\end{array}$ \\
\hline & $(\mu \mathrm{M})$ & \multicolumn{7}{|c|}{$(\mu \mathrm{g} / \mathrm{mL})$} \\
\hline 1 & 0.04 & $\leq 0.125$ & 4 & 8 & $\leq 0.125$ & 32 & 4 & 5 \\
\hline 2 & 2.0 & 2 & 16 & $>128$ & $2-4$ & $>128$ & $>128$ & 16 \\
\hline 3 & 0.16 & $\leq 0.125$ & 2 & $8-16$ & $\leq 0.125$ & $\geq 128$ & 8 & 10 \\
\hline 4 & 1.6 & 2 & 2 & 32 & 2 & 32 & 32 & 3 \\
\hline 5 & 5.0 & 2 & 2 & $>128$ & 2 & $>128$ & 64 & nd \\
\hline 6 & 3.2 & 4 & 4 & 128 & 4 & 64 & 64 & 5 \\
\hline 7 & 7.9 & 4 & 4 & $>128$ & 4 & $>128$ & 128 & 5 \\
\hline 8 & 10 & 2 & 2 & 64 & 2 & 32 & 32 & 3 \\
\hline
\end{tabular}

Table 2. Biochemical, bacterial susceptibility and cardiac ion channel data for 5,6-fused gyrase inhibitors 3 and 9-12.

\begin{tabular}{|c|c|c|c|c|c|c|c|c|c|}
\hline Cmpd & $\begin{array}{c}\text { DNA } \\
\text { Gyrase } \\
\mathrm{IC}_{50}\end{array}$ & $\begin{array}{c}\text { E.coli } \\
\text { TOP10 } \\
\Delta t o l C\end{array}$ & $\begin{array}{c}\text { E.coli } \\
\text { TOP10 } \Delta \text { tolC } \\
\text { GyrB E793K }\end{array}$ & $\begin{array}{c}\text { E.coli } \\
7623\end{array}$ & $\begin{array}{c}\text { E.coli } \\
7623 \\
\Delta t o l C\end{array}$ & $\begin{array}{c}\text { A. } \\
\text { baumannii } \\
\text { BM4454 }\end{array}$ & $\begin{array}{c}\text { Cytotoxicity } \\
\quad \mathrm{TC}_{50}\end{array}$ & $\begin{array}{c}\text { hERG } \\
\text { IC }_{\mathbf{5 0}}{ }^{17} \\
(\mu \mathrm{M})\end{array}$ & $\begin{array}{l}\mathbf{N a} \mathbf{v}_{\mathbf{1}} \mathbf{1 . 5} \\
\mathbf{I C}_{50}{ }^{18} \\
(\mu \mathrm{M})\end{array}$ \\
\hline & $(\mu \mathrm{M})$ & \multicolumn{6}{|c|}{$(\mu \mathrm{g} / \mathrm{mL})$} & & \\
\hline 1 & 0.04 & $\leq 0.125$ & 4 & 8 & $\leq 0.125$ & 4 & 5 & 6.7 & 13 \\
\hline 3 & 0.16 & $\leq 0.125$ & 2 & $8-16$ & $\leq 0.125$ & 8 & 10 & 23 & 22 \\
\hline 9 & 0.5 & 1 & 16 & 64 & 1 & 64 & 20 & nd & 24 \\
\hline 10 & 1.6 & 8 & 16 & $>128$ & 4 & $>128$ & 5 & 3.6 & 16 \\
\hline 11 & 0.5 & 0.25 & 8 & 64 & 0.25 & 32 & 3 & nd & nd \\
\hline 12 & 0.16 & 0.25 & 0.5 & 8 & 0.25 & 4 & 11 & 9.5 & nd \\
\hline
\end{tabular}

\section{Acknowledgments}

Some of the research leading to these results received funding from the Innovative Medicines Initiative Joint Undertaking under Grant Agreement 115583, resources of which are composed of financial contribution from the European Union's Seventh Framework Programme (FP7/2007-2013) and the in-kind contributions of European Federation of Pharmaceutical Industries and Associations (EFPIA) companies. The ENABLE project is also financially supported by contributions from academic and small-medium enterprise (SME) partners. We thank Gaochao Tian, Mehul Patel, Jeffrey Carson and Tony Jurewicz (GSK) for development of the high throughput gyrase assay, Hong-Wei Sun (GSK) for synthetic assistance, Luz Helena Kryn for the cytotoxicity data, Pierre Despeyroux and Frédéric Jeannot (Evotec) for assistance with re-preparing some analogs and Eric Bacqué (Evotec) for critical reading of the manuscript.

\section{References and notes}

1. Piddock, L.J.V. The crisis of no new antibiotics-what is the way forward? Lancet Infect. Dis. 2012, 12, 249-253.

2. Spellberg, B.; Guidos, R.; Gilbert, R.; Bradley, J.; Boucher, H. W.; Scheld, W. M.; Bartlett, J. G.; Edwards, J. The Epidemic of Antibiotic-Resistant Infections: A Call to Action for the Medical Community from the Infectious Diseases Society of America. Clin. Infect. Dis. 2008, 46, 155-164.
3. President's Council of Advisors on Science and Technology (2014) Report to the President on Combating Antibiotic Resistance, 2014. Available at https://obamawhitehouse. archives.gov/sites/default/files/microsites/ostp/PCAST/pcast_amr jan2015.pdf. Accessed February 1, 2017,

4. See https://www.un.org/pga/71/event-latest/high-level-meetingon-antimicrobial-resistance/.

5. Simpkin, V.I.; Tenwick, M. J.; Kelly, R. Mossialos, E. Incentivizing innovation in antibiotic drug discovery and development: progress, challenges and next steps. J. Antibiotics. 2017, 170, 1087-1096.

6. See: http://nd4bb-enable.eu/

7. Chan, P. F.; Germe, T. Bax, B. D.; Huang, J.; Thalji, R. K.; Bacqué, E.; Checchia, A.; Chen, D.; Cui, H.; Ding, X. Ingraham, K.; McCloskey, L.; Raha, K; Srikannathasanc, V.; Maxwell, A.; Stavenger R. A. Thiophene antibacterials that allosterically stabilize DNA-cleavage complexes with DNA gyrase. Proc. Natl. Acad. Sci. USA. 2017, 114, E4492-E4500.

8. Chan, P.F.; Huang J.; Bax B.D.; Gwynn, M.N. (2013) Recent developments in inhibitors of bacterial type IIA topoisomerases. Antibiotics: Targets, Mechanisms and Resistance, eds Gualerzi CO, Brandi L, Fabbretti A, Pon CL (Wiley, Weinheim, Germany), pp 263-297.

9. a) Taylor, S.N.; Morris, D.H.; Avery, A.K.; Workowski, K.A.; Batteiger, B.E.; Tiffany, C.A.; Perry, C.R.; Raychaudhuri, A; Scangarella-Oman, N.E.; Hossain, M.; Dumont, E.F. Gepotidacin for the Treatment of Uncomplicated Urogenital Gonorrhea: A Phase 2, Randomized, Dose-Ranging, Single-Oral Dose Evaluation. Clin. Infect. Dis. 2018, 67, 504-512. b) Basarab, G. S.; Kern, G. H.; McNulty, J. Mueller, J. P.; Lawrence, K; Vishwanathan, K.; Alm, R. A.; Barvian, K.; Doig, P.; Galullo, V.; Gardner, H.; Gowravaram, M.; Huband, M; Galullo, V.; Gardner, H.; Gowravaram, M.; Huband, M.; Kimzey, A.; Morningstar, M; Kutschke, A.; Lahiri, S. D.; Perros, M.; Singh, R.; Schuck, V. J. A.; 
Tommasi, R.; Walkup, G.; Newman, J.V. Responding to the challenge of untreatable gonorrhea: ETX0914, a first-in-class agent with a distinct mechanism-of-action against bacterial Type II topoisomerases. Sci. Rep. 2015, 5, 11827.

10. a) Zheng, Y.; Tice, C.M.; Singh, S.B. Conformational control in structure-based drug design. Bioorg. Med. Chem. Lett. 2017, 27, 2825-2837. b) Fang, Z.; Song, Y.: Zhan, P.; Zhang, Q.; Liu, X. Conformational restriction: an effective tactic in 'follow-on'-based drug discovery. Future Med. Chem. 2014, 6, 885-901.

11. High-throughput DNA gyrase biochemical assay was developed based on a preferential enhancement of fluorescence of a H19 dye following binding to supercoiled DNA compared to relaxed DNA. Test compounds were incubated at room temperature for 1 hour with $15 \mu \mathrm{g} / \mathrm{ml}$ relaxed pBR322 DNA (Topogen or Inspiralis), 60 $\mathrm{nM}$ of His-tagged E.coli DNA gyrase and $2.5 \mathrm{mM}$ ATP in an assay buffer of $20 \mathrm{mM}$ Tris- $\mathrm{HCl}, 35 \mathrm{mM} \mathrm{NH}_{4} \mathrm{OAc}$ (pH 8), $8 \mathrm{mM} \mathrm{MgCl}_{2}$, $4.6 \%$ glycerol, $0.005 \%$ Brij35 and $1 \mathrm{mM}$ DTT. Relaxed and supercoiled DNA forms were detected following incubation with a 1 in 400 dilution of $\mathrm{H} 19$ dye (ProFoldin) and fluorescence intensity reading with Ex: $485 \mathrm{~nm}$ and Em: $530 \mathrm{~nm}$. See also: Asha, M. K.; Debraj, D.; Prashanth, D; Edwin, J. R.; Srikanth, H. S.; Muruganantham, N.; Dethe, S. M.; Anirban, B.; Jaya, B.; Deepak, M.; Agarwal, A. In vitro anti-Helicobacter pylori activity ofaflavonoidrichextract of Glycyrrhizaglabra and its probable mechanisms of action. J. Ethnopharmacol. 2013, 145, 581-586.

12. Antibacterial MIC assays were determined according to Clinical and Laboratory Standards Institute guidelines: Clinical and Laboratory Standards Institute (2009) Methods for Dilution Antimicrobial Susceptibility Tests for Bacteria That Grow Aerobically: Approved Standard. (CLSI, Wayne, PA), 8th Ed, Publication M07-A8.

13. Concha, N. O.; Huang, J.; Bai, X.; Benowitz, A. B.; Brady, P. G.; LaShadric, C. G.; Kryn, L. H.; Holmes, D.; Ingraham, K.; Jin, Q.; Kaushanaky, L. P.; McCloskey, L.; Messer, J. A.; O'Keefe, H.; Patel, A,; Satz, A. L.; Sinnamon, R. H.; Schneck, J. L.; Skinner, S. S.; Summerfield, J.; Taylor, A. N.; Taylor, J. D.; Evindar, G.; Stavenger, R. A. Discovery and characterization of a class of pyrazole inhibitors of bacterial undecaprenyl phyrophosphate synthase. J. Med. Chem. 2016, 59, 7299-7304.

14. Du, D.; Wang-Kan, X.; Neuberger, A.; van Veen, H.W.; Pos, K.M.; Piddock, L.J.V.; Luisi, B.F. Multidrug efflux pumps: structure, function and regulation. Nat. Rev. Microbiol. 2018, 16, 523-539.

15. The $2.7 \AA$ complex of compound 3 was obtained using the doublenicked 20-12p-8 DNA (which has an artificial nick at each cleavage site) and was deposited in the PDB with code: $6 \mathrm{qx} 1$; its structure was determined as described for some other structures with the same DNA - see Srikannathasan, V.; Wohlkonig, A.; Shillings, A.; Singh, O.; Chan, P.F.; Huang, J.; Gwynn, M.N.; Fosberry, A.P.; Homes, P.; Hibbs, M.; Theobald, A.J.; Spitzfaden, C.; Bax, B.D Crystallization and initial crystallographic analysis of covalent DNA-cleavage complexes of Staphyloccocus aureus DNA gyrase with QPT-1, moxifloxacin and etoposide' Acta Crystallogr. Sect. F Struct. Biol. Cryst. Commun. 2015, 71, 1242-1246 for details. Then to try and obtain a clear view of compound $\mathbf{3}$ with cleaved DNA, a DNA-cleavage complex was purified and co-crystallized with compound 3: A 1.4 fold excess of uncleaved DNA 20-447T (dimer, 2 mM DNA, sequence in Srikanathasan et al., 2015) and a 50-fold excess of moxifloxacin was added to $S$. aureus GyrB27-A56 (GKdel) in $20 \mathrm{mM}$ HEPES, $100 \mathrm{mM} \mathrm{Na}_{2} \mathrm{SO}_{4}, 5 \mathrm{mM} \mathrm{MnCl}_{2}$, pH 7.0 and then applied to a Superdex S200 10/300 column (GE Healthcare 17517501) in a running buffer of $20 \mathrm{mM}$ HEPES $\mathrm{pH}$ 7.0, $100 \mathrm{mM} \mathrm{Na} \mathrm{SO}_{2}$ and $20 \mathrm{mM}$ EDTA to remove the moxifloxacin, Mn ions and excess DNA. The fractions containing the gyrase/DNA complex (with no drug) were pooled and concentrated to approximately $15 \mathrm{mg} / \mathrm{ml}$. Crystallization: The DNA/protein complex was diluted 2:1 with $20 \mathrm{mM}$ HEPES pH 7.0 to reduce the $\mathrm{Na}_{2} \mathrm{SO}_{4}$ concentration and compound $\mathbf{3}$ was added to an end concentration of approximately $600 \mu \mathrm{M}$ compound and $5 \%$ DMSO. Crystallization under paraffin oil was set up in Terazaki plates with $0.7 \mu 1$ protein and $2.8 \mu 1$ well buffer $(7.5-10 \%$ PEG 5000 MME, 130-190 mM BisTris pH 6.2). The crystallizations were set up in the presence and absence of $25 \mathrm{mM} \mathrm{MgCl}_{2}$. Before adding the oil, the drops were streak-seeded. The crystals were cryo-protected in 15\% Glycerol, 20\% PEG $5000 \mathrm{MME}, 150 \mathrm{mM}$ BisTris pH6.2, 2 mM EDTA, 2 mM compound before flash freezing in liquid nitrogen for data collection at the synchrotron. This complex of compound 3 with cleaved DNA gave a $3.4 \AA$ structure with six complexes in the asymmetric unit deposited with PDB code: $6 \mathrm{qx} 2$.
16. E.coli topoisomerase IV assays were performed as follows: $1 \mathrm{U}$ of topo IV (final assay concentration $15 \mathrm{nM}$ ) was incubated with 200 ng kDNA DNA in a $30 \mu \mathrm{l}$ reaction at $37^{\circ} \mathrm{C}$ for 30 minutes under the following conditions: $50 \mathrm{mM}$ HEPES-KOH (pH 7.6), $100 \mathrm{mM}$ potassium glutamate, $10 \mathrm{mM}$ magnesium acetate, $10 \mathrm{mM}$ dithiothreitol, $1 \mathrm{mM}$ ATP and $50 \mu \mathrm{g} / \mathrm{ml}$ BSA.

Human topoisomerase II alpha assays were performed as follows: $1 \mathrm{U}$ of human topo II $\alpha$ (final assay concentration $1.9 \mathrm{nM}$ ) was incubated with $200 \mathrm{ng}$ kDNA in a $30 \mu \mathrm{l}$ reaction at $37^{\circ} \mathrm{C}$ for 30 minutes under the following conditions: $50 \mathrm{mM}$ Tris $\mathrm{HCl}(\mathrm{pH} 7.5)$, $125 \mathrm{mM} \mathrm{NaCl}, 10 \mathrm{mM} \mathrm{MgCl} 2,5 \mathrm{mM}$ DTT, $0.5 \mathrm{mM}$ EDTA, 0.1 $\mathrm{mg} / \mathrm{ml}$ bovine serum albumin (BSA) and $1 \mathrm{mM}$ ATP.

All reactions were stopped by the addition of $30 \mu \mathrm{l}$ chloroform/isoamyl alcohol $(24: 1)$ and $20 \mu \mathrm{l}$ Stop Dye $(40 \%$ sucrose, $100 \mathrm{mM}$ Tris. HCl ( $\mathrm{pH}$ 7.5), $10 \mathrm{mM}$ EDTA, $0.5 \mu \mathrm{g} / \mathrm{ml}$ bromophenol blue), before being loaded on a $1.0 \%$ TAE (Tris.acetate $0.04 \mathrm{mM}$, EDTA $0.002 \mathrm{mM}$ ) agarose gel. Gels were run at $90 \mathrm{~V}$ for 2 hours. Bands were visualised by ethidium bromide staining for 20 minutes. Gels were scanned using gel documentation equipment (GeneGenius, Syngene, Cambridge, UK) and $\mathrm{IC}_{50} \mathrm{~S}$ were obtained with gel scanning software. (GeneTools, Syngene, Cambridge,UK) Raw gel data (fluorescent band volumes) collected from Syngene, GeneTools gel analysis software were converted to a $\%$ of the $100 \%$ control (the fully decatenated substrate) These were analysed using SigmaPlot Version 13.0 (2015). (Enzymes and substrates provided by Inspiralis Ltd)

17. hERG Qpatch assay as previously described in: Haile. P.A.; Casillas, L.N.; Bury, M. J.; Mehlmann, J.F.; Singhaus, Jr., R.; Charnley, A.K.; Hughes, T.V.; DeMartino, M.P.; Wang, G.Z.; Romano, J.J.; Dong, X.; Plotnikov, N.V.; Lakdawala, A.S.; Convery, M.A.; Votta, B.J.; Lipshutz, D.B.; Desai, B.M.; Swift, B.; Capriotti, C.A.; Berger, S.B.; Mahajan, M.K.; Reilly, M.A.; Rivera, E.J.; Sun, H.H.; Nagilla, R.; LePage, C.; Ouellette, M.T.; Totoritis, R.D.; Donovan, B.T.; Brown, B.S.; Chaudhary, K.W.; Gough, P.J.; Bertin, J.; Marquis, R.W. Identification of Quinoline-Based RIP2 Kinase Inhibitors with an Improved Therapeutic Index to the hERG Ion Channel. ACS Med. Chem. Lett. 2018, 26, 1039-1044..

18. $\mathrm{Na}_{\mathrm{V}} 1.5$ Qpatch assay: Cell culture, assay solutions and growth medium are identical to that described in Donovan, B.T.; Bakshi, T.; Galbraith, S.; Nixon, C.J.; Payne, L.A.; Martens, S.F. Utility of frozen cell lines in medium throughput electrophysiology screening of hERG and Nav1.5 blockade. J. Pharmacol. Toxicol. Methods, 2011, 64, 269-276, with the following exceptions: Cell line: The HEK293-based $\mathrm{Na}_{V} 1.5$ expressing cell line was derived in-house by GSK Biological Reagents and Assay Design group. The parental cell line, the ATCC line HEK293 cell line CRL-1573 was transfected with the Homo sapiens cardiac sodium voltage-gated channel, $\mathrm{hNa}_{\mathrm{V}} 1.5$ (type $\mathrm{V}, \alpha$ subunit, SCN5A, Entrez gene id: 6331). For $\mathrm{Na}_{\mathrm{V}} 1.5$ experiments, all protocols were sampled at 20 $\mathrm{kHz}$ and filtered with a 4th order Bessel filter with a $200 \mathrm{~Hz}$ cutoff. Series resistance was compensated at $50 \%$. The holding potential was $-120 \mathrm{mV}$. The stimulus protocol consisted of holding each cell at $-120 \mathrm{mV}$ for $20 \mathrm{~ms}$, stepping to $-30 \mathrm{mV}$ for $50 \mathrm{~ms}$ and returning to the $-120 \mathrm{mV}$ holding potential. The command protocol was delivered every $2 \mathrm{~s}(0.5 \mathrm{~Hz})$. A separate assay was run with the command protocol delivered every $500 \mathrm{~ms}(2 \mathrm{~Hz})$ to check for signs of frequency dependent effects on potency. Data reported in Table 2 correspond to the $0.5 \mathrm{~Hz}$ assay. Signal was measured at each sweep was the difference between the maximum inward current seen in the first $10 \mathrm{~ms}$ of the $-30 \mathrm{mV}$ depolarizing step minus the mean current seen in the last $5 \mathrm{~ms}$ of the same step. Currents were recorded at room temperature on the Sophion Qpatch 48 HTX (Sophion Biosciences). Cells which had $\mathrm{Na}_{\mathrm{V}} 1.5$ currents greater than $0.25 \mathrm{nA}$ were used for experiments, although the amplitude was usually much higher $(\sim 2.5 \mathrm{nA})$. For all concentration response curve experiments, a negative control consisting of external solution with $0.3 \%$ DMSO bracketed the concentration-response dilution series. After the second negative control was added, a positive control of $1000 \mu \mathrm{M}$ quinidine was added to fully block all current. Inhibition data were normalized between the negative and positive controls. All solutions on each plate were matched for vehicle concentration, $0.3 \%$ DMSO. Above that concentration peak current amplitude dropped significantly. In all experiments, each test solution concentration was added three times $(10 \mu \mathrm{l}$ each addition for $30 \mu \mathrm{l}$ total, $3 \mathrm{~s}$ apart) and given $5 \mathrm{~min}$ to reach steadystate. Rundown compensation, where necessary, was done with a linear fit anchored to the end of the control state. Curve fitting: all signals were analyzed using Sophion Qpatch software version 5.0. Data was collated using Microsoft Excel and all subsequent 
analyses were done using GraphPad Prism version 6.05 for

Windows (GraphPad Software, La Jolla, California USA,

www.graphpad.com). Measurements were fit to a four-parameter logistic fit for dose-response curves: $\mathrm{y}=$ bottom + (top-bottom) / $\left(1+10^{\wedge}\left(\left(\log \mathrm{EC}_{50}-\mathrm{x}\right) *\right.\right.$ Hill slope $\left.)\right)$. 